\title{
THE EDITOR'S CORNER
}

We are very pleased to announce the appointment of Helen Frey Rochlin as Associate Editor of the Business History Review. Ms. Rochlin is a graduate of Barnard College, where she studied history. Since 1970 she has been Senior Course Assistant in the Written Analysis of Cases (now Written and Oral Communication) course at the Harvard Business School. She will handle a wide range of editorial tasks, and we are delighted to welcome her to our staff.

We are pleased to announce the following appointments to the Editorial Advisory Board of the Business History Review, which took effect on July 1, 1974: François Crouzet, Professor of History, University of Paris-Sorbonne; David Herlihy, Professor of History, Harvard University; Thomas P. Hughes, Professor of the History and Sociology of Science, University of Pennsylvania; Thomas K. McCraw, Associate Professor of History, University of Texas, Austin; Eric H. Robinson, Professor of History, University of Massachusetts, Boston; and S. B. Saul, Professor of Economic History, University of Edinburgh.

To Professors Derek H. Aldcroft, Robert D. Cuff, Jürgen Kocka, Peter Mathias, Harry N. Scheiber, and to Mira Wilkins, who have completed their appointments, we express our sincere appreciation for their assistance and counsel.

The Harvard University Graduate School of Business Administration and the Newcomen Society in North America announce a Postdoctoral Fellowship in Business History in the amount of $\$ 13,000$ to be awarded for twelve-months' residence, study, and research at the Harvard Business School during 1975-1976. The Newcomen Fellowship in Business History will be awarded for half this period. The remainder of the Fellowship and its associated expenses will be covered by a grant from the Harvard Business School.

The purpose of this award is to assist a Ph.D. graduate under the age of thirty-five to improve his professional acquaintance with business and economic history, improve his skills as they relate to this field, and to engage in research that will benefit from the resources of the Harvard Business School and the Boston scholarly community. The Fellows' doctoral degree may be in history, economics, or a related discipline such as sociology. The successful applicant will be asked to participate in the School's business history course and seminar and take at least one other formal course of instruction based on his particular needs or interests. $\mathrm{He}$ will also be expected to take part during the academic year in some aspect of the Business History Group's activity, such as assisting in the publication of the Business History Review. At least half the total time, however, will be available for research of the Fellow's own choosing in the field of business history. 
Inquiries should be addressed to Professor Alfred D. Chandler, Jr, Morgan Hall 207, Harvard University Graduate School of Business Administration, Boston, Massachusetts 02163. Applicants will be asked to state their purpose in applying for the Fellowship, the specific area in which they would like to do course work, and the topic, objectives, and design for the research to be undertaken. Final applications should be accompanied by graduate school records, letters from three persons in support of the application, and such other evidence as the applicant wishes to submit.

The selection committee, which will be composed of faculty members of the Harvard Business School, will interview candidates where possible and will make its award to the applicant whose background and plans seem most likely to benefit from the resources offered. The successful applicant may begin his twelve-months' residence on either July 1 or September 1, 1975 .

Applications must be completed by April 1, 1975. The Fellowship will be awarded and all applicants notified by April 15, 1975. Material submitted with application will be returned only if accompanied by postage and a self-addressed return envelope.

The Southwest Labor History Conference will be held on April 24-26, 1975 at the University of the Pacific, Stockton, California, under the auspices of the Pacific Center for Western Historical Studies. The sessions will be divided into two general areas: (1) southwest labor history and (2) national and international labor history. Scholars and trade unionists are invited to submit session proposals in areas including press, labor and politics, labor and race, women and labor, agricultural labor, Chicano labor, labor and socialism, labor in Mexico, international labor, comparative trade union movements. Address all program inquiries to: Professor Sally M. Miller, Department of History, University of the Pacific, Stockton, California 95204.

The Eleutherian Mills Historical Library, Wilmington, Delaware, has announced recent acquisitions which include papers of the Antietam Manufacturing Company, a wool manufacturing concern of Hagerstown, Maryland, as well as pamphlets and correspondence on the single tax movement.

The Library's 1974 Grants-in-Aid were awarded to: Richard Tedlow, Columbia University (public relations and business from 1918-1952); Roy Lopata, University of Delaware (John J. Raskob's political career); and Edward Duggan, Thomas More College (labor supply and technological change in the nineteenth century).

We sincerely regret that an erroneous price was listed in the review of Sidney Ratner's Tariff in American History in our Winter, 1973 issue. The correct price is $\$ 2.95$. The error was not the fault of the reviewer, but of the Review, and we extend our apologies to all concerned.

Among books recently received but not reviewed are the following: Sterling G. Slappey, ed., Pioneers of American Business (Grosset \& Dun- 
lop, New York, 1973, \$7.95), an assortment of thumbnail sketches and illustrations pertaining to approximately fifty American businesses; Brian Roberts, The Diamond Magnates (Charles Scribner's Sons, New York, $1973, \$ 8.95)$, a journalistic view of the industry in South Africa; and John S. Wright and Parks B. Dimsdale, Jr., eds., Pioneers in Marketing (School of Business Administration, Georgia State University, 1974, \$4.95), sketches of the lives and accomplishments of twenty-five persons, most of which were previously published in the Journal of Marketing. In addition, the following publications may be of interest: a reprint of Ira B. Cross's 1935 History of the Labor Movement in California (University of California Press, Berkeley, 1974, \$14.50); Derek H. Aldcroft, Studies in British Transport History: 1870-1970 (David \& Charles, Newton Abbott, 1974, $f 5.50$ ), a collection of thirteen essays, eleven of which were published elsewhere originally; William L. Blackwell, ed., Russian Economic Development from Peter the Great to Stalin (Franklin Watts, New York, 1974, \$5.95), fourteen previously published pieces, several available in English for the first time in this volume; Roderick Floud, ed., Essays in Quantitative Economic History (Oxford University Press, New York, 1974, \$17.75), all previously published essays with an introduction by the editor; and an especially noteworthy assortment, Peter Earle, ed., Essays in European Economic History, 1500-1800 (Oxford University Press, New York, 1974, \$16.00), English translations of eleven major, previously published essays by leading European scholars, including Fernand Braudel and Emmanuel Le Roy Ladurie.

On October 25, 1974 the Eleutherian Mills Historical Library will sponsor a conference entitled Financing Business in the Nineteenth Century. Papers will be delivered by Daniel Hodas, former Postgraduate Research Fellow, Eleutherian Mills Historical Library, on "The Merchant as Financeer: Financing America's Early Transportation System" and Julian Skaggs, Widener College, on "Lukens Steel: A Case Study of Internal Financing." Glenn Porter, Harvard University, will act as commentator, and Herman Krooss, New York University, will serve as session chairman. Anyone desiring further information please contact Barbara E. Benson, Eleutherian Mills Historical Library, Greenville, Wilmington, Deleware 19807. 